\title{
Studies with the Mutation, Diabetes, in the Mouse*
}

\author{
D. L. Coleman and Katharine P. Hommel \\ The Jackson Laboratory, Bar Harbor, Maine
}

Summary. The mutation, diabetes $(d b)$, that occurred in the C57BL/Ks strain of mice is a unit autosomal recessive gene with full penetrance, and causes metabolic disturbances in homozygous mice resembling diabetes mellitus in man. Abnormal deposition of fat at 3 to 4 weeks of age is followed by hyperglycemia, polyuria and glycosuria. The diabetic condition appears to develop in two stages. In the early stage, there are marked increases in the levels of plasma insulin, the rates of lipogenesis, gluconeogenesis, and glucose oxidation, and there is a reduction of $\beta$-cell granules in the islet of Langerhans with other changes suggestive of a compensating adaptation to increased insulin demand. On the other hand, the late stage is eharacterized by a near normal level of circulating insulin, a marked decrease in glucose utilization but with a continued high rate of gluconeogenesis. These findings suggest a defect in the peripheral utilization of insulin rather than in the synthesis and release of the hormone from the pancreas.

Etudes de la mutation «diabète» chez la souris

Résumé. La mutation, diabète $(d b)$, a été observée dans la souche de souris C57BL/Ks. C'est un gène autosomal récessif avec pénétrance complète, et qui mène chez les homozygotes à un trouble métabolique ressemblant au diabète sucré chez l'homme. Une accumulation excessive de graisses se produit à l'âge de $3-4$ semaines et est bientôt suivie par l'apparition d'hyperglycémie, de polyurie et de glucosurie. L'évolution clinique suit ensuite deux étapes. Durant la première, les taux d'insuline plasmatique sont élevés et la lipogénèse, la gluconéogénèse, ainsi que l'oxydation du glucose sont accélérées; il y a diminution de la granulation des cellules $\beta$ et d'autres altérations suggérant l'existence d'une compensation d'un état nécessitant une utilisation insulinique accrue. La deuxième étape, par contre, est caractérisée par des taux normaux d'insuline plasmatique, avec diminution marquée de l'utilisation du glucose malgré la persistance d'une gluconéogénèse nettement exagérée. Ces observations nous semblent indiquer l'existence d'une utilisation défectueuse de l'insuline à la périphérie, plutôt qu'une anomalie primaire de la synthèse ou de la libération de l'hormone au niveau du pancréas.

Unterswchungen bei der Mutation ,Diabetes" der Maus.

Zusammenfassung. Die Mutation Diabetes $(d b)$, die in dem Mäusestamm C57BL/Ks auftritt, ist ein autosomales rezessives Gen mit voller Penetranz und verursacht bei homzygoten Mäusen eine dem im Menschen auftretenden Diabetes mellitus ähnliche Stoffwechselstörung: übermäßige Ablagerung von Fett im Alter von 3-4 Wochen, mit anschließender Hyperglykämie, Polyurie und Glucosurie. Der klinische Verlauf erfolgt dann in zwei Phasen. In der ersten Phase ist ein wesentlicher Anstieg der Plasmainsulinwerte im Vordergrund, mit Beschleunigung von Lipogenese, Gluconeogenese und Glucoseoxydation. Das Abnehmen der Granula in den $\beta$-Zellen der Langerhansschen Inseln und andere Veränderungen deuten auf eine Anpassung an einen steigenden Insulinbedarf. In der zweiten Phase, dagegen, sind die Insulinspiegel eher normal, und der Glucoseverbrauch nimmt ab, bei Weiterbestehen der beschleunigten Gluconeogenese. Diese Ergebnisse deuten eher auf eine mangelhafte periphere Insulinwirkung als auf eine ungenügende Synthese der Ausschüttung des Hormones durch das Pankreas.

Key-words: Spontaneous Diabetes, Genotype: C57BL/ K5-db, Diabetes in mice, Mutation: diabetes, Obesity, Prediabetes, Insulin in plasma, Insulin in pancreas. Islets of Langerhans, Pancreas, Insulin resistance, Glucose utilization, Gluconeogenesis
Diabetes $(d b)$, a new mutation in the mouse, which

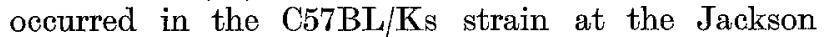
Laboratory, is a unit autosomal recessive gene. The disease is characterized by metabolic disturbances resembling those of maturity-onset diabetes mellitus in man [11]. All mice homozygous for the diabetes gene $(d b / d b)$ become diabetic, the first distinguishing feature being a marked tendency to obesity with large fat depositions observed in the axillary and inguinal regions at about 3 to 4 weeks of age. Blood sugar concentrations in normal mice range from 130 to $160 \mathrm{mg} / 100 \mathrm{ml}$, but in diabetic mice concentrations as high as $300 \mathrm{mg} / 100 \mathrm{ml}$ may occur as early as 4 weeks. of age; more often this elevation occurs between 5 and 8 weeks. In older diabetic mice blood sugar concentrations greater than $600 \mathrm{mg} / 100 \mathrm{ml}$ are not

* Supported in part by United States Public Health services grant \# AM 06871 from the National Institute of Arthritis and Metabolic Diseases and grant \# HD 00468 from the National Institute of Human Development. urrcommon. Other symptoms observed after the blood sugar concentration has reached 250 to $300 \mathrm{mg} / 100$ $\mathrm{ml}$ are glycosuria, polydipsia, polyuria, and polyphagia. Marked histological changes in organs and tissues of diabetic mice have been observed only in the islets of Langerhans. The islets of the diabetics are not clearly demarcated from pancreatic acinar cells, and contain few, if any beta granules. Transitions to islet and pancreatic acinar cells have been observed in the cells lining the cyst-like pancreatic ducts suggesting that neogenesis of islet tissue may occur to compensate for insulin depletion. This report describes some of the histological and biochemical changes that accompany the development of diabetes.

\section{Materials and Methods}

Diabetic mice used in these studies were from the inbred $\mathrm{C} 57 \mathrm{BL} / \mathrm{Ks}-d b$ strain and from an outerossed heterogeneous stock. Controls were normal C57BL/Ks 
mice generously provided by Dr. NaTHaN KaLISS. All diabetic mice are infertile and thus must be produced by mating together heterozygous carriers of the diabetic gene $(d b /+\times d b /+)$. Because of greater reproductive vigor in heterozygous mice of the outcrossed stock, some diabetics used in these studies were of this heterogeneous origin. However, a few diabetic mice of the inbred strain were included in each of the studies and no differences between outcross and inbred lines have become apparent.

All mice were housed in stainless steel pens on pine shavings with pelleted food and tap water available at all times. The pelleted food was a standard mouse chow manufactured by the Emory Morse Company of Guilford, Connecticut, containing $11 \%$ of protein and $6 \%$ of fat.

Mice were killed at various ages from newborn to 11 months, most being between 2 and 6 months when sacrified. For histological studies, organs were fixed in modified Bouin's (10\% rather than $25 \%$ formalin) or Fekete's modification of Tellyesniczky's fluid [14], embedded in paraffin, routinely sectioned at $8 \mu$, and stained with hematoxylin and eosin. The aldehyde fuchsin technique of Gomori as modified by HaLMI [7] was used to stain the $\beta$-cell granules in the islets of Langerhans in 5-6 $\mu$ sections of Bouin-fixed pancreas. For identification of glycogen, periodic acid Schiff (PAS), with and without pretreatment with diastase, was used on Tellyesniczky-fixed pancreas, liver, kidney and heart. Among the organs fixed were pancreas, thyroid, adrenal, pituitary, ovary, testis, liver, kidney, heart, retina, and lung.

For therapy studies, two oral hypoglycemic agents were employed: phenethylbiguanide hydrochloride, a generous gift from the U.S. Vitamin \& Pharmaceutical Corporation, Yonkers, New York, and tolbutamide, generously provided by the Upjohn Company, Kalamazoo, Michigan.

Liver lipid was determined according to the procedure of FolCH et al., [2]. Glycogen was isolated and determined with the anthrone reagent [8]. Estimations of protein in whole homogenates were made using the biuret method with bovine serum albumin as a standard. The spectrophotometric protein assay of WARBURG and Christian [24] was used to determine protein in supernatant solutions after high speed centrifugation. Blood sugar concentrations were measured by the micromethod of Folin and Marmros [3] on $50 \mu \mathrm{l}$ of blood obtained from the orbital sinus of fed mice. Plasma insulin was determined by an immunological procedure essentially the same as that described by Halks and Randue [6] using bovine insulin as a standard and the insulin- ${ }^{125} \mathrm{I}$ immunoassay kit supplied by The Radiochemical Centre, Amersham, England.

Enzymes were assayed in liver and adipose tissue of the gonadal fat pads by standard procedures as described in the references following the enzyme listing. Glucokinase [18], glucose-6-phosphate dehy- drogenase [13], and fructose-1,6-diphosphatase [16] were measured in the $100000 \times \mathrm{g}$ supernatant solution described by Sharira et al. [18]. Citrate lyase and acetyl-CoA synthetase were measured in the 100000 $\times g$ supernatants as prepared by KORNACKER and Lowenstein [12]. Glucose-6-phosphatase [20], phosphoenolpyruvate carboxykinase [22], and pyruvate carboxylase [21] were assayed in whole liver homogenates. The assay used for pyruvate carboxylase involved measuring the rate of $\mathrm{NaH}^{14} \mathrm{CO}_{3}$ incorporation into oxaloacetate as described in Table 1 of reference 21.

\section{Results}

All mice homozygous for the trait, diabetes $(d b)$, develop an abnormal and characteristic deposition of fat beginning at 3 to 4 weeks of age, making their early identification possible. The difference in size and appearance of litter-mate 6 -week old mice, one normal and one diabetic, is shown in Fig. 1. Weight increases

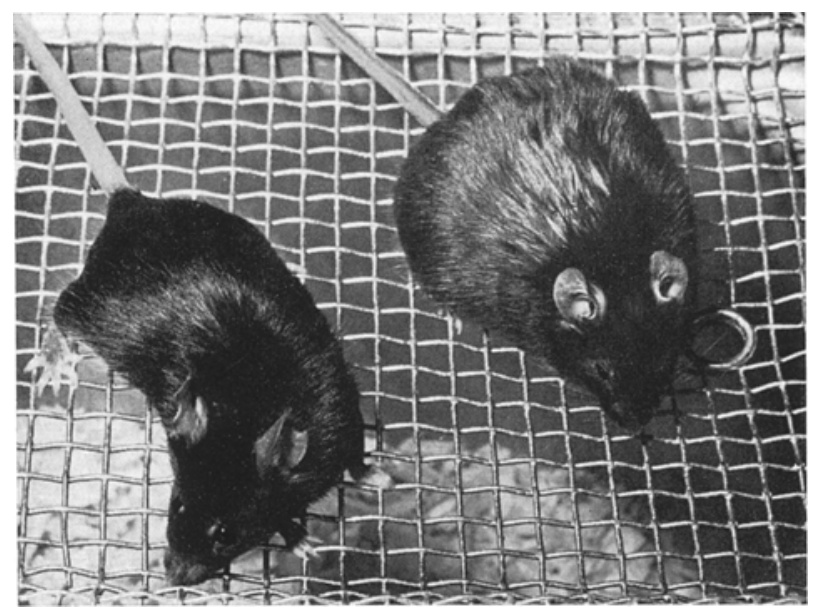

Fig. 1. C57BL/Ks- $\not b$ litter-mates at 6 weeks. The diabetic mouse on the right weighs 50 per cent more than the control mouse on the left and shows typical fat deposition.

with age and concomitant elevations of blood sugar concentration have been described previously [11] and will not be dealt with in detail here. Although there are individual variations in the age of onset of diabetes and the rate of increase in weight and blood sugar concentration, there is a general pattern, which is depicted in Fig. 2. In many of these diabetic mice blood sugar concentration tends to increase gradually between 5 and 12 weeks of age, after which it may rise sharply to over $500 \mathrm{mg} / 100 \mathrm{ml}$ of blood almost overnight. The diabetic condition, thus, appears to develop in two phases, an early one when there is some regulation of blood sugar concentration, and a later stage characterized by a marked increase in hyperglycemia and a complete loss of metabolic control.

A few exceptional diabetics, usually females, exhibit a pattern similar to that shown in Fig. 3. Although 
obviously obese, they maintain blood sugar concentrations of 200 to $250 \mathrm{mg} / 100 \mathrm{ml}$, levels only slightly above normal, for periods up to 3 months and a sharp rise, if it appears at all, does not occur until much later. Others, usually males, have blood sugar concentrations exceeding $400 \mathrm{mg} / 100 \mathrm{ml}$ as early as 5 weeks of age.

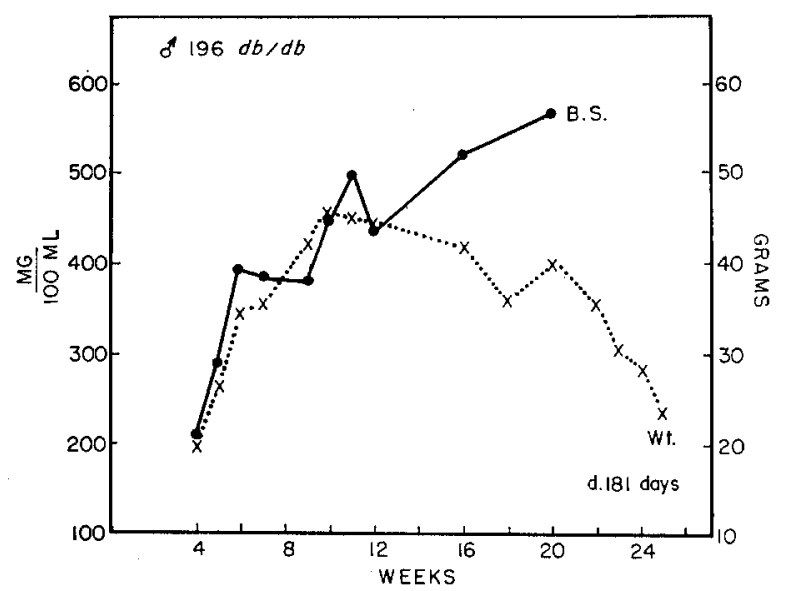

Fig. 2. Curves showing increases in weight $(x \ldots x)$ and blood sugar concentration ( - ) with age in a representative diabetic mouse

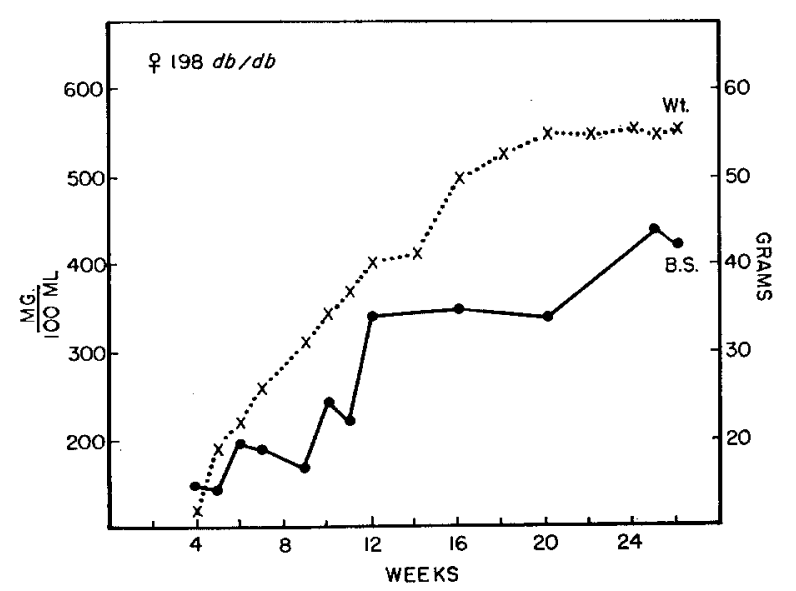

Fig. 3. Curves of weight $(x \ldots x)$ and blood sugar concentration ( $-\bullet)$ with age in a less typical diabetic mouse

Aside from the large accumulations of fat, subcutaneously in axillary and inguinal regions and intraabdominally in mesenteric and gonadal fat pads, the most striking anatomical deviation is the size of the liver. The liver may weigh up to 4.5 grams in a 40 gram mouse, compared with 1.2 grams in a 20 gram normal mouse. Table 1 shows the average composition of liver from 10 normal and 10 diabetic mice 2 months of age in $\mathrm{mg}$ per $\mathrm{g}$ wet weight of liver. Lipid and glycogen are both increased with compensating decreases in protein and water content. Assays of livers of older diabetic mice have indicated that the lipid and glycogen content remains high even in advanced stages of the disease.
Many of the liver cells of the diabetic mouse are hypertrophied and filled with fat droplets, especially in areas surrounding the hepatic veins (Fig. 5). The increase in glycogen content seen in Table 1 is not visible histologically as PAS-positive, diastase-digestible material, but a striking difference in glycogen distribution in livers from normals and from diabetics is apparent. In normal liver (Fig. 4), glycogen is distributed fairly uniformly throughout, whereas in that from the diabetic (Fig. 5), glycogen is massed in the cells surrounding the hepatic arteries and hepatic portal veins and is reduced or lacking in cells near the hepatic veins. Reasons why glycogen should collect in cells near the blood inflow and fat in cells near the outflow are obscure.

Table 1. Composition of livers from normal and diabetic mice two months of age

\begin{tabular}{lcc}
\hline Constituent & Normal & Diabetic \\
\hline Protein & \multicolumn{2}{c}{ mg/g wet weight of liver } \\
Fat & $196 \pm 7$ & $170 \pm 7$ \\
Glycogen & $34 \pm 1$ & $79 \pm 3$ \\
Water & $29 \pm 4$ & $51 \pm 3$ \\
& $687 \pm 17$ & $654 \pm 14$
\end{tabular}

The ovaries, uteri, and mammary glands of diabetics are atrophic and histologically in a state resembling that occurring after hypophysectomy. In the ovaries, there are no follicles beyond the antrum stage and no corpora lutea or evidence of ovulation. The uterus and mammary glands are juvenile in appearance. Testes are small and contain few tubules with active spermatogenesis. Other endocrine glands (thyroid, adrenal, and pituitary) show no obvious abnormalities but have not been studied in great detail.

No pathology was seen in kidneys, hearts, and lungs and no cataracts or retinal hemorrhages were seen in the eyes of diabetics of any age. However, it must be emphasized that special techniques were not employed and that histological studies were done only with light microscopy.

The islets of Langerhans are the only organs that show alterations with the advance of the diabetic condition. The islets do not appear to differ in number and size from those of controls but they do differ greatly in the number of granulated $\beta$-cells visible (Fig. 6 and 7). Degranulation of $\beta$-cells is a consistent finding and apparently occurs as early as the onset of obesity as it is evident in the islets of 25 -day old diabetics. The number of granulated $\beta$-cells, and the density of staining as well, is greatly reduced as the disease progresses.

In addition to degranulation, there are other changes such as loss of clear boundaries between the islet cells and acinar cells of the exocrine pancreas and the appearance of dilated pancreatic ducts among islet cells (Fig. 8). In this islet from a 20-week old diabetic female, some functional $\beta$-cells remain 
scattered among other unidentifiable cellular components, and some of the epithelial cells of the dilated. ducts appear to be undergoing transitions to islet cells. proliferated duct epithelium (Fig. 9) and "budding" of islets from a large pancreatic duct (Fig. 10) have not been observed in pancreases from normal mice.

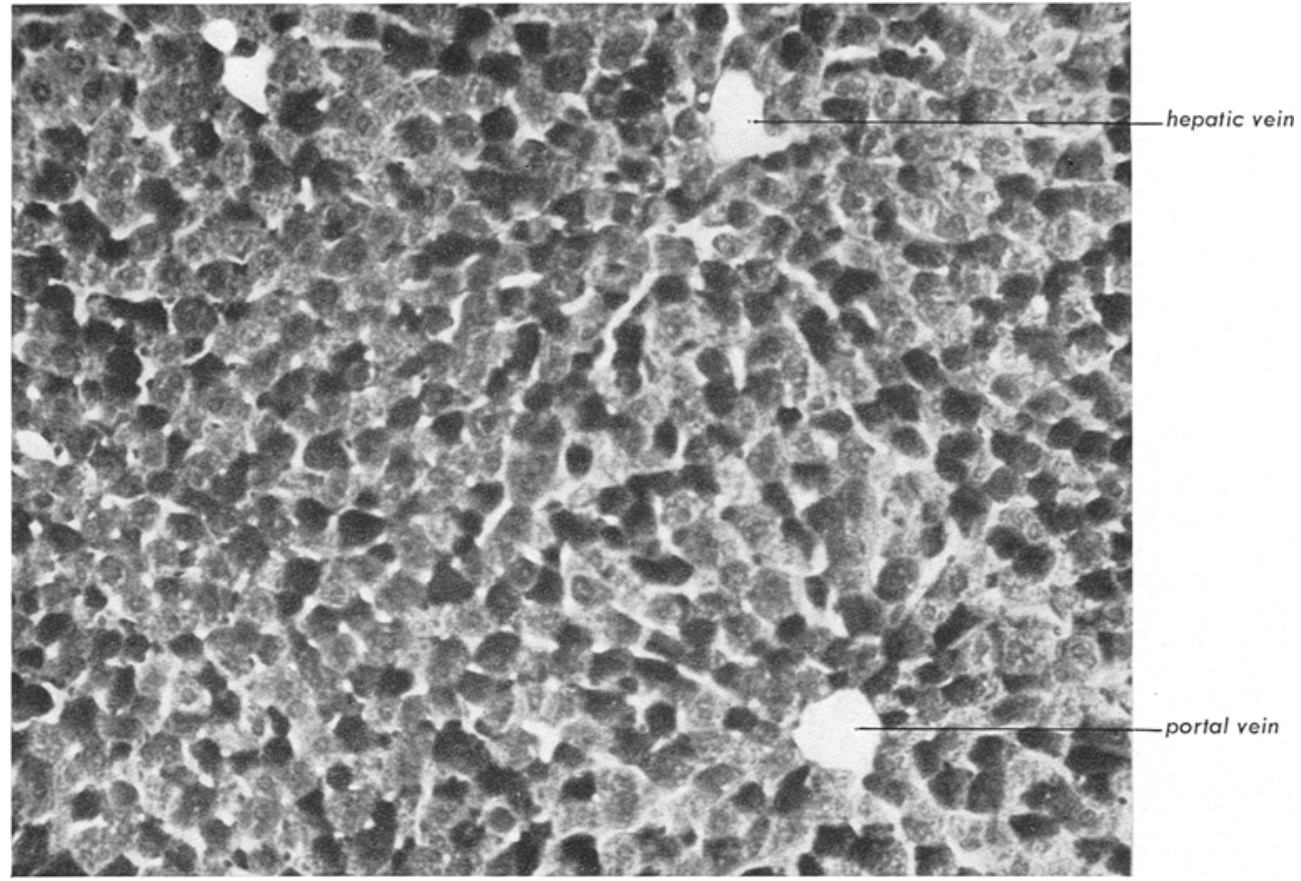

Fig. 4. Liver from a normal control mouse. PAS stain. $\times 200$

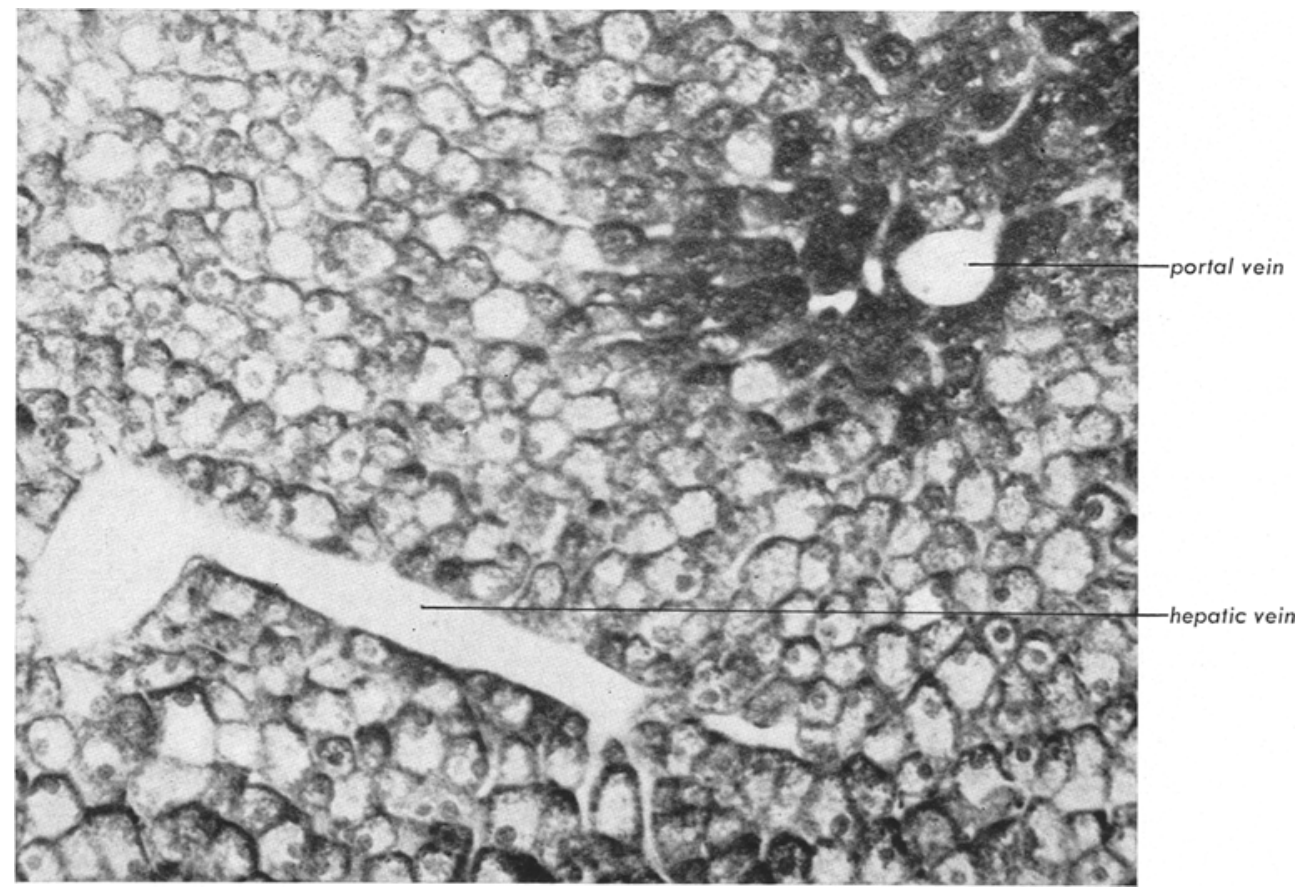

Fig. 5. Liver from a diabetic mouse with a glycogen assay of $61.4 \mathrm{mg} / \mathrm{g}$ and a blood sugar concentration of $404 \mathrm{mg} / 100 \mathrm{ml}$. PAS stain. $\times 200$

The formation of islet tissue from pancreatic duct epithelium occurs normally during embryonic life and ceases neonatally. Association of islet cells with greatly
Thus, it appears that in the diabetic mouse depletion of intracellular insulin, as evidenced by degranulation of $\beta$-cells, leads to proliferation of pancreatic ducts 
and neogenesis of islet cells from them. Glycogenic vacuolization, commonly seen in islet cells of some other diabetic rodents $[4,5]$ has not been observed.

Metabolic studies in vivo. The rates of production of respiratory ${ }^{14} \mathrm{CO}_{2}$ from uniformly labeled ${ }^{14} \mathrm{C}$-glucose peritoneally and then placing each mouse immediately into a cylindrical glass chamber. Compressed air, from commercial cylinders of water-pumped gas, was directed through a column of Drierite to remove moisture and then into the mouse chamber. The air flow was regulated to one liter per minute. The effluent gas containing ${ }^{14} \mathrm{CO}_{2}$ was redried and passed through the ionization chamber. The resultant graph was used to calculate the total ${ }^{14} \mathrm{CO}_{2}$ expired (usually in $2 \frac{1}{2} \mathrm{hr}$ ), the ${ }^{14} \mathrm{CO}_{2}$ expired during the first $30 \mathrm{~min}$ utes, and the maximum rate of ${ }^{{ }^{14}} \mathrm{CO}_{2}$ expired. The magnitude of these three measurements was dependent on the dose of ${ }^{14} \mathrm{C}$-glucose administered but was identical when calculated per microcurie of glucose injected. In a typical experiment $2 \mu$ auries of ${ }^{14} \mathrm{C}$ glucose per mouse was used. Results were converted to total $\mathrm{CO}_{2}$ output by correcting for the dilution of radioisotope that occurs in diabetic mice because of the relatively large glucose pool. Typical results in 4 diabetic mice at various stages of the diabetic condition are shown in Table 2. A rather unexpected finding was that diabetic mice in the early diabetic stage are capable of converting glucose to carbon dioxide much more efficiently than normal control mice. Not only was the total recovery of carbon dioxide greater for the $2^{1 / 2} \mathrm{hr}$ period but also the maximum rate of ${ }^{14} \mathrm{CO}_{2}$ production was markedly elevated. This increased ability to metabolize glucose gradually diminished as the diabetic mice got older and the condition became more

Table 2. Conversion of glucose to carbon dioxide in diabetic mice

\begin{tabular}{|c|c|c|c|c|}
\hline Mouse & $\begin{array}{l}\text { Blood } \\
\text { sugar }\end{array}$ & $\begin{array}{l}\text { Total glucose } \\
\text { metabolized }\end{array}$ & $\begin{array}{l}\text { Glucose con- } \\
\text { verted in 1st } \\
30 \mathrm{~min} \text {. }\end{array}$ & $\begin{array}{l}\text { Maximum } \\
\text { rate }\end{array}$ \\
\hline & $\begin{array}{l}\mathrm{mg} / 100 \\
\mathrm{ml}\end{array}$ & $\begin{array}{l}\% \text { of } \\
\text { normal }\end{array}$ & $\begin{array}{l}\% \text { of } \\
\text { normal }\end{array}$ & $\begin{array}{l}\% \text { of } \\
\text { normal }\end{array}$ \\
\hline Q76 & 285 & 185 & 300 & 326 \\
\hline$\delta^{7} 71$ & 370 & 143 & 159 & 165 \\
\hline 우76 & 350 & 135 & 75 & 127 \\
\hline 871 & 450 & 90 & 49 & 79 \\
\hline 우7 & 481 & 57 & 39 & 56 \\
\hline 956 & 540 & 32 & 30 & 39 \\
\hline
\end{tabular}

were measured in vivo with a commercial instrument (Dynacon 6000, Nuclear Chicago) that consists of a continuous flow ionization chamber connected to an electrometer and a graphic integrating recorder. Mice were studied singly by injecting ${ }^{14} \mathrm{C}$-glucose intra- severe. When the blood sugar concentration approached $500 \mathrm{mg} / 100 \mathrm{ml}$ (at 2 to 3 months of age) glucose metabolism was slightly less than normal even when the data were corrected for the ever increasing size of the glucose pool in diabetic mice. Mice ( $\# 56$ and 57) were litter-mates one of which $(\# 57)$ developed hyperglycemia more slowly than the other. However, glucose metabolism was severely decreased in both of these mice at 4 months of age, although $\# 57$ showed a somewhat greater ability to metabolize glucose. The residual glucose metabolism seen in all diabetic mice with blood sugar concentrations greater than $500 \mathrm{mg} /$ $100 \mathrm{ml}$ may be due to metabolism of glucose via the pentose shunt. However, experiments designed to test this possibility, utilizing glucose labelled specifically were inconclusive.

Enzyme studies. Insulin has been demonstrated to be a necessary prerequisite for the maintenance of normal levels of glucokinase in liver [18], and for the 
maintenance of citrate lyase [12] and glucose-6-phosphate dehydrogenase [25] in both liver and adipose tissue. Animals pancreatectomized or rendered diabetic with alloxan have markedly decreased levels of these enzymes and injected insulin increases the activities of these enzymes to normal or greater than normal levels. Young diabetic mice, at the stage when they still have an increased capacity to utilize glucose, had increased hepatio activities of glucokinase, citrate lyase and acetyl-CoA synthetase (Table 3). However, glucose-6-phosphate dehydrogenase activity in the livers of mice in early diabetic stages was not quite as great as in normal livers. This enzyme may be the most sensitive to the action of insulin of the four enzymes mentioned since the livers of some diabetic mice in the group had glucose-6-phosphate dehydrogenase activity equal to that from normal mice. Thus the overall decrease in activity in livers from the group of 12 diabetic mice probably includes data from a few mice in the transitional stage when the ability to metabolize glucose was rapidly declining. Activities of all four enzymes in liver from older diabetic mice with blood sugar concentrations approaching $600 \mathrm{mg} / 100 \mathrm{ml}$ were greatly reduced.

Enzyme activities in adipose tissue showed the same general patterns as those in liver with the exception that glucose-6-phosphate dehydrogenase was clearly elevated in adipose tissue from the younger diabetic mice over that seen in adipose tissue from normal controls. Acetyl-CoA synthetase was within the normal range in adipose tissue from the younger diabetic mice but in older mice with more advanced stages of diabetes this enzyme was

Fig. 7. Pancreas from a 5 to 6 week old diabetic mouse showing extensive degranulation of $\beta$-cells, Aldehyde fuchsin stain. $\times 400$

Table 3. Activities of some insulin dependent enzymes in liver and adipose tissues of normal and diabetic mice

\begin{tabular}{|c|c|c|c|c|c|}
\hline Genotype & Tissue & $\begin{array}{l}\text { Glucose-6-phosphate } \\
\text { dehydrogenase }\end{array}$ & Citrate lyase & $\begin{array}{l}\text { Acetyl-CoA } \\
\text { synthetase }\end{array}$ & Glucokinase \\
\hline & & \multicolumn{4}{|c|}{$\mu$ moles product produced $/ \mathrm{hr} / \mathrm{mg}$ of protein ${ }^{1}$} \\
\hline$+1+$ & Liver & $0.952 \pm 0.062$ & $0.435 \pm 0.038$ & $0.322 \pm 0.037$ & $0.506 \pm 0.055$ \\
\hline $\begin{array}{l}a b / d b \\
\text { (young })^{2}\end{array}$ & Liver & $0.741 \pm 0.071$ & $1.38 \pm 0.17$ & $0.568 \pm 0.068$ & $0.855 \pm 0.010$ \\
\hline $\begin{array}{l}d b / d b \\
(\text { old })^{2}\end{array}$ & Liver & $0.258 \pm 0.026$ & $0.364 \pm 0.100$ & $0.201 \pm 0.053$ & 0 to 0.30 \\
\hline$+1+$ & Adipose & $14.1 \pm 1.2$ & $1.20 \pm 0.11$ & $0.197 \pm 0.015$ & - \\
\hline $\begin{array}{l}d b / d b \\
\text { (young) })^{2}\end{array}$ & Adipose & $30.4 \pm 0.9$ & $1.85 \pm 0.24$ & $0.218 \pm 0.024$ & - \\
\hline $\begin{array}{l}d b / d b \\
(\text { old })^{2}\end{array}$ & Adipose & $10.7 \pm 0.8$ & $<0.39$ & $<0.10$ & - \\
\hline
\end{tabular}

${ }^{1}$ Figures represent enzyme activities \pm standard error of the mean and are based on $\mu$ moles product produced, i.e., for glucose-6-phosphate dehydrogenase, $\mu$ moles of TPNH; for eitrate lyase and acetylCoA synthetase, $\mu$ moles of acetyl-CoA; and for glucokinase, mmoles of glucose-6-phosphate.

2 The young diabetic mice were under 3 months of age and had blood sugar coneentrations of less than $300 \mathrm{mg} \%$, whereas the old diabetic mice were over 3 months of age with blood sugar concentrations approaching $600 \mathrm{mg} \%$. 
almost undetectable. Similarly, the activities of citrate lyase and glucose-6-phosphate dehydrogenase were greatly decreased in these older diabetic as compared the diabetic mice have attained maximum weight, after which no further accumulation of adipose tissue is noted.

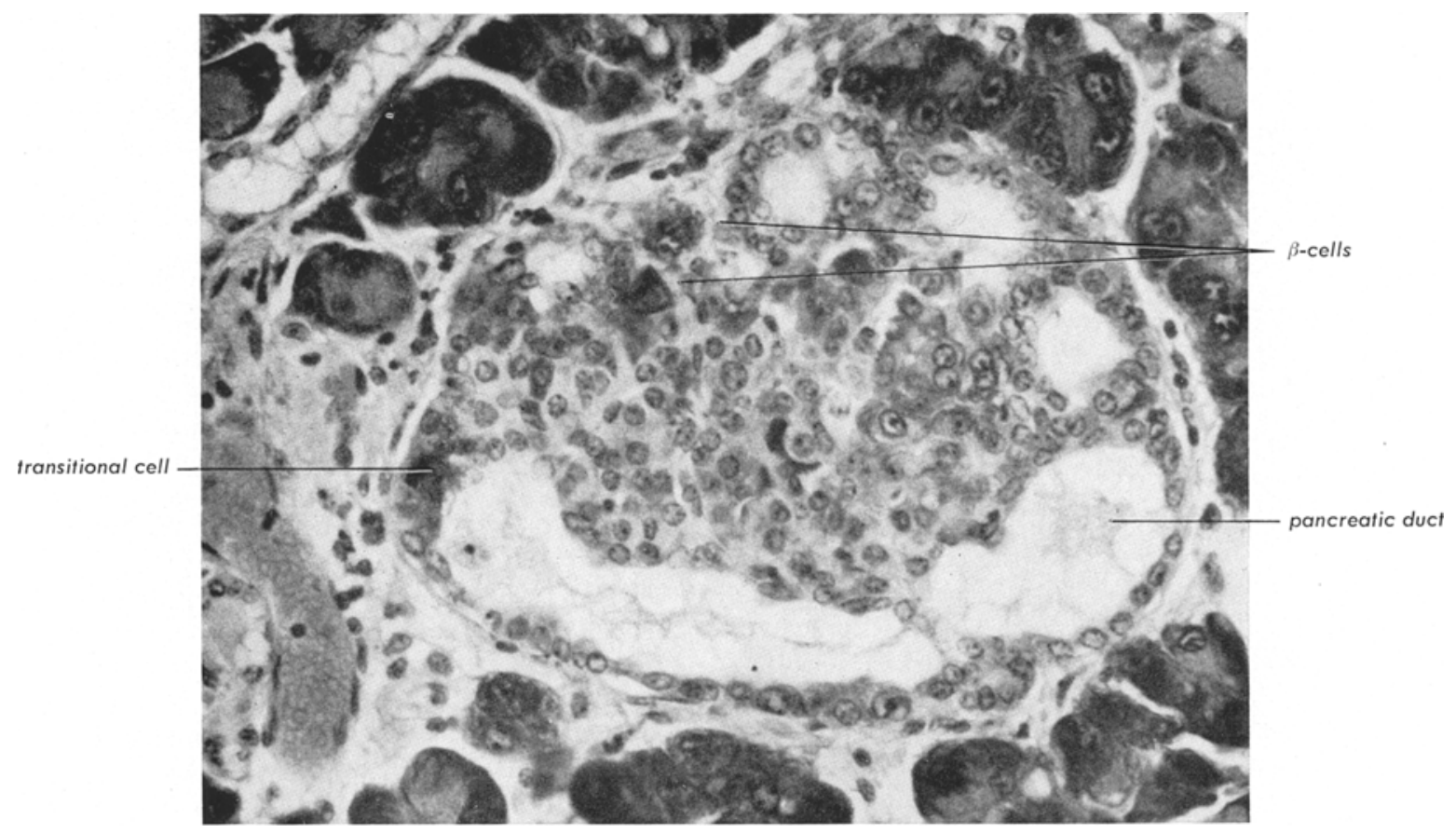

Fig. 8. Pancreas from a 20 week old diabetic mouse; islet contains degranulated $\beta$-cells and dilated pancreatic ducts with transitional cells in the epithelium. Aldehyde fuchsin stain. $\times 400$

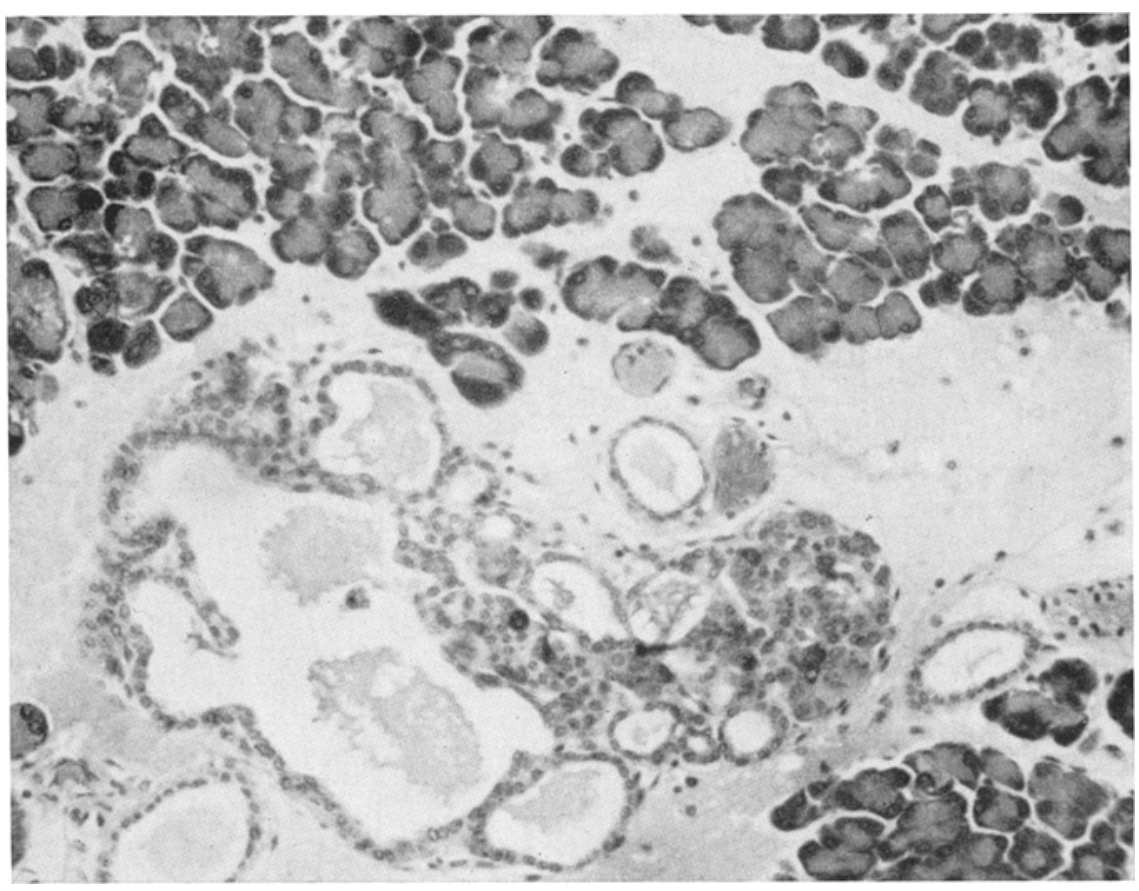

Fig. 9. Pancreas from a 20 weets old diabetic mouse showing extensive proliferation of duct epithelium and neogenesis of islet cells. Aldehyde fuchsin stain. $\times 200$

either with younger diabetic mice or normal controls. The period of greatly decreased activity of these insulindependent enzymes corresponds to the period when
Increases in activity of the insulin-dependent enzymes in the early stages of diabetes suggest that there may be normal or even increased insulin levels 
in diabetic mice. If so, the gluconeogenic enzymes, which are increased in some experimental types of diabetes and decreased in the presence of adequate insulin [26], would be expected to be normal or decreased in the early-stage diabetic mice. In fact, sugar concentrations ranging from 210 to $343 \mathrm{mg} / 100$ $\mathrm{ml}, 13$ diabetic mice over 12 weeks of age with blood sugar concentrations over $500 \mathrm{mg} / 100 \mathrm{ml}$, and 2 exceptional diabetic mice 13 weeks of age with blood sugar concentrations of 184 and $257 \mathrm{mg} / 100 \mathrm{ml}$. An

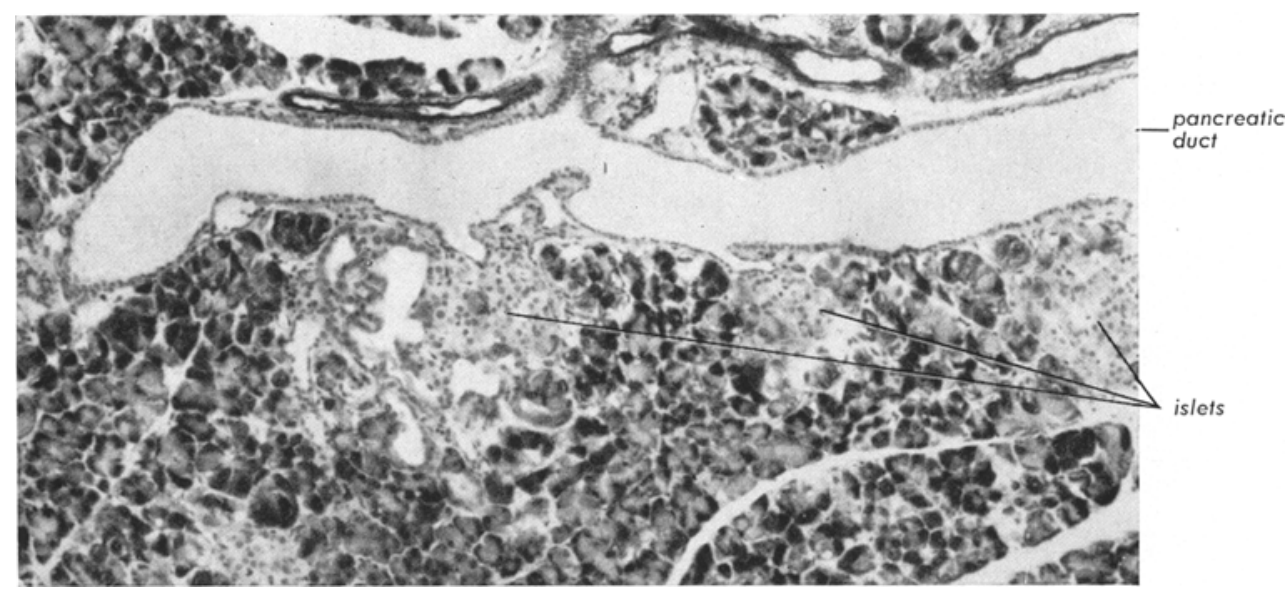

Fig. 10. Pancreas from a 12 week old diabetic mouse showing several islets budded from a pancreatic duct. $\mathrm{H}$ and $\mathrm{E}$ stain. $\times 130$

Table 4. Hepatic activities of the key gluconeogenic enzymes in normal and diabetic mice

\begin{tabular}{llllll}
\hline Genotype & Blood sugar & $\begin{array}{l}\text { Glucose-6- } \\
\text { phosphatase }\end{array}$ & $\begin{array}{l}\text { Fructose-1,6- } \\
\text { diphosphatase }\end{array}$ & $\begin{array}{l}\text { Pyruvate } \\
\text { carboxylase }\end{array}$ & $\begin{array}{l}\text { Phosphoenol- } \\
\text { pyruvate } \\
\text { carboxykinase }\end{array}$ \\
\hline & $\mathrm{mg} / \mathbf{1 0 0 \mathrm { ml }}$ & $\mu$ moles product $/ \mathrm{hr} / \mathrm{g}$ wet weight of liver & \\
$+/+$ & $\mathbf{1 3 0 - 1 6 0}$ & $\mathbf{8 1 7} \pm \mathbf{2 3}$ & $151 \pm 11$ & $20.6 \pm 1.0$ & $\mathbf{1 0 . 8} \pm 0.8$ \\
$d b / d b$ & $<250$ & $1360 \pm 90$ & $200 \pm 12$ & $26.5 \pm 1.7$ & $\mathbf{1 6 . 6} \pm 1.3$ \\
$d b / d b$ & $>250$ & $1360 \pm 90^{2}$ & $200 \pm 12^{2}$ & $26.5 \pm 1.7^{2}$ & $24.3 \pm 1.4$
\end{tabular}

1 Enzymes were assayed as outlined in the text. The activities are expressed in $\mu$ moles of product produced, \pm standard error of the mean. Products measured were phosphate for glucose-6-phosphatase and fructose-1,6-diphosphatase, and $\mu$ moles ${ }^{14} \mathrm{CO}_{2}$ fixed in oxaloacetate for pyruvate carboxylase and phosphoenolpyruvate carboxykinase.

2 The values for the two classes blood sugar $(<250$ or $>250 \mathrm{mg} / 100 \mathrm{ml}$ ) of diabetic mice were not significantly different and the figures represent the combined values from both types.

the activities of glucose-6-phosphatase, fructose-1,6diphosphatase, pyruvate carboxylase, and phosphoenolpyruvate carboxykinase in livers from diabetic mice at all stages of the disease were all increased over those observed in normal liver (Table 4). Thus, the action of insulin on gluconeogenesis is not apparent in the diabetic mice. However, a suggestion that insulin exerts partial control over gluconeogenesis is observed since the activity of phosphoenolpyruvate carboxykinase in liver from younger diabetic mice is not as greatly increased as it is in liver from older diabetics with blood sugar concentrations greater than $250 \mathrm{mg} / 100 \mathrm{ml}$.

Plasma insulin assay. Plasma immunoreactive insulin was determined in triplicate on $0.1 \mathrm{ml}$ aliquots of plasma from the following mice: $16 \mathrm{C} 57 \mathrm{BL} / \mathrm{Ks}$ normal control mice 1 to 3 months of age with blood sugar concentrations ranging from 140 to $160 \mathrm{mg} / 100$ $\mathrm{ml}$; 14 diabetic mice 4 to 5 weeks of age with blood average value of $328 \mu \mathrm{U} / \mathrm{ml}$ (range $117-500 \mu \mathrm{U}$ ) was established for the 14 young diabetic mice compared with a normal value of $60 \mu \mathrm{U} / \mathrm{ml}$ in the 16 normal mice (range $35-100 \mu \mathrm{U}$ ). In contrast, the average plasma insulin value for the 13 diabetic mice over 12 weeks of age with blood sugar concentrations over $500 \mathrm{mg}$ / $100 \mathrm{ml}$ was $62 \mu \mathrm{U} / \mathrm{ml}$ (range $44-81 \mu \mathrm{U}$ ). These data clearly demonstrate that the diabetic mice do not lack insulin early in the course of the disease but actually have an excess of insulin, which is apparently nonfunctional as far as controlling the blood sugar concentration and the rate of gluconeogenesis. As the disease develops, the plasma insulin levels decrease markedly, reaching normal values at about the time active glucose metabolism stops. The two exceptional diabetic mice 13 weeks of age with rather well controlled diabetes (blood sugar 184 and $257 \mathrm{mg} / 100 \mathrm{ml}$ ) had plasma immunoreactive insulin concentrations of 256 and $510 \mu \mathrm{U}$ of insulin per $\mathrm{ml}$ respectively. These 
same two mice at 17 weeks of age had even higher plasma insulin concentrations of 600 and $800 \mu \mathrm{U} / \mathrm{ml}$ and the blood sugar concentration remained 170 and $260 \mathrm{mg} / 100 \mathrm{ml}$. They are probably typical of those few mice that develop diabetes more slowly and do not tax the pancreatic insulin supply as severely early in the course of the disease.

Attempts at therapy. Attempts to keep the weight of diabetic mice within normal limits by total or partial food restriction resulted in premature deaths. After it was discovered that gluconeogenesis is greatly increased in diabetic mice, attempts were made to regulate blood sugar levels and also weight gain by feeding rations devoid of carbohydrate. The progress of diabetic mice placed on this ration at 6 weeks of age has been followed for 3 months (Table 5). The diet

Table 5. Effect of a carbohydrate-free diet on diabetic mice

\begin{tabular}{|c|c|c|c|c|}
\hline \multirow{2}{*}{ Mouse } & \multicolumn{4}{|c|}{ Blood sugar $(\mathrm{mg} / 100 \mathrm{ml})$} \\
\hline & start & 1 month & 2 months & 3 months \\
\hline ta223 & 159 & 275 & 160 & 191 \\
\hline 8225 & 278 & 213 & 169 & 237 \\
\hline Q209 & 250 & 316 & 352 & 355 \\
\hline ð226 & 335 & 353 & 407 & 356 \\
\hline శ224 & 426 & 375 & 378 & 452 \\
\hline $\begin{array}{l}\text { Diabetic } \\
\text { (normal di }\end{array}$ & 246 & 460 & 500 & 548 \\
\hline
\end{tabular}

1 These values for diabetic mice on a normal diet are average values which have been determined on from $10-20$ diabetic mice.

selected consisted of casein, $87 \%$; corn oil, $5 \%$; nonnutritive cellulose, 3\%; Wesson salts, $5 \%$; and adequate amounts of all known vitamins [1]. The normal mice (not shown in Table 5) all showed normal weight gains and had blood sugar concentrations only slightly below normal. Of 12 diabetic mice initially selected for this study, 2 died after one week on the ration while the other 10 showed no ill effects. As can be seen in Table 5, those mice with the lowest blood sugar concentrations at the start seemed to respond best to the carbohydrate-free ration. Two of the mice had blood sugar concentrations only slightly above normal at the end of the 3 month period, while two others stabilized at the starting blood sugar concentrations. Weight gains of diabetic mice on this ration, were, on the whole, variable but somewhat smaller than those seen on the chow ration. However, those diabetic mice that showed the greatest decrease in rate of weight gain did not necessarily have the lowest blood sugar concentrations at the end of the treatment period.

Four normal and four diabetic female mice were sacrificed after 2 months on this diet and their livers assayed for pyruvate carboxylase and phosphoenolpyruvate carboxykinase. The activity of pyruvate carboxylase in normal liver was increased from 20.6 in mice on the normal ration to 27.0 units ( $\mu$ moles oxaloacetate produced per hour per gram of liver) in mice on the carbohydrate-free diet. Similarly the activity of the carboxykinase was increased from 10.8 in chow-fed normal mice to 23.1 units in normal mice fed the carbohydrate-free ration. These elevated enzyme activities in normal mice on the carbohydratefree diet were almost identical to those observed in chow-fed diabetic mice (Table 4). In contrast, no further elevation in the activity of either of these enzymes was observed in livers from diabetic mice fed the carbohydrate-free ration compared with diabetic mice fed the chow ration, suggesting that these gluconeogenic enzymes are fully induced in the diabetic state.

Livers and pancreases from two of the normal and two of the diabetic mice killed after 2 months on the carbohydrate-free diet were examined for histological changes. Distribution of glycogen and fat in liver cells followed the patterns described above for normal and diabetic mice, indicating that no appreciable changes had taken place. Islets from the normal mouse contained fully granulated $\beta$-cells, whereas those from the diabetic mouse showed degranulation and the other changes seen in diabetic mice on complete rations.

Injections of 1 unit of protamine zine insulin (Lilly) twice a day were effective in maintaining blood sugar concentrations within the normal range for a brief period if treatment was initiated in the younger mice before the blood sugar concentration reached $250 \mathrm{mg} / 100 \mathrm{ml}$. In older mice with blood sugar concentrations over $250 \mathrm{mg} / 100 \mathrm{ml}$, injections of up to $100 \mathrm{units} /$ $100 \mathrm{~g}$ were completely ineffective in reducing blood sugar to normal levels. Continued treatment of young diabetic mice with daily injections of insulin, although controlling blood sugar concentrations initially, did not prevent or delay either the obesity or the uncontrollable high blood sugar concentrations, which usually develop at about 6 to 8 weeks of age.

Treatment of diabetic mice with the oral hypoglycemic agent, tolbutamide, in doses up to $15 \mathrm{mg}$ per day has so far been ineffective and doses above this amount have proved to be toxic. Another hypoglycemic agent, phenethylbiguanide, administered in the drinking water $(1.25 \mathrm{mg} / \mathrm{ml})$, was successful in maintaining normal blood sugar levels in only a few cases. Of 10 mice treated, 4 died within 2 weeks after initiation of the treatment, 3 showed little or no response, and in the 3 others blood sugar concentration remained within normal limits for 3 months. In the latter three, body weights were stabilized at that seen when treatment was initiated. However, no actual weight losses were seen and the relative obesity of these mice was still apparent.

\section{Discussion}

The marked tendency to obesity, the increased activities of several insulin-dependent enzymes, and the degranulation of $\beta$-cells of the islets of Langerhans observed in the younger diabetic mice are quite con- 
sistent with the increased levels of circulating insulin found in these mice. That the levels of these enzymes decrease markedly in the later stages of diabetes when plasma insulin levels are near normal is also not unexpected. However, the persistence, in the presence of increased circulating insulin, of much higher than normal levels of the enzymes involved in regulating gluconeogenesis is inconsistent and suggests a defect in one of the more important peripheral actions of insulin. A similar defect in peripheral effectiveness of plasma insulin has been noted in the diabetic sand rat [5].

The reasons for the ineffectiveness of this excess circulating insulin in maintaining normal blood sugar concentration and in regulating the rate of gluconeogenesis are obscure. A possibility, which cannot be excluded, is the presence of insulin antagonists [23]. However, their presence seems unlikely in view of the potent action of insulin in sustaining lipogenesis and in increasing glycolysis in these mice. Also excess secretion of growth hormone, ACTH, and corticosteoids may be counteracting one or more of the normal functions of insulin [27] and it has been shown that ACTH-secreting tumors cause abnormal fat deposits and islet hypertrophy, hyperplasia, and $\beta$-cell degranulation [9]. A general hormonal dysfunction in diabetic mice is suggested by their atrophic gonads and associated structures, as well as by their failure to reproduce.

Although granulated $\beta$-cells in the islets of Langerhans of diabetic mice are greatly reduced, they apparently retain the ability to synthesize and release normal or above normal amounts of insulin in the early stages of the disease. Degranulation of $\beta$-cells most probably represents the result of increased secretion rather than decreased ability to synthesize insulin; supporting this is the high levels of plasma insulin. The sequence leading to frank diabetes might be increased $\beta$-cell stimulation, resulting in increased activity to the point of exhaustion, neogenesis of $\beta$ cells, which become exhausted in turn, until eventually the demand for insulin exceeds the compensatory capacity of islet tissue. However, the nature of the initial stimulus to the $\beta$-cells is not elear. Hyperglycemia appears to be ruled out by the observation that degranulation of $\beta$-cells is observed in diabetic mice 25 days old when the blood sugar concentration is at a normal level. A temporal association between onset of obesity and $\beta$-cell degranulation has been established but a common causal association has not.

Associations of obesity, hyperglycemia, hyperinsulinism, $\beta$-cell degranulation, and islet hyperthrophy have been observed in mice of several stocks, notably yellow obese $\left(A^{Y}\right)[10]$, obese $(o b)[15], \mathrm{NZO}[19]$, KK [17], and the spiny mouse (Acomys) [4]. The degree of dependence of adiposity, hyperglycemia, and islet, hypertrophy on food consumption varies among these mice, but in all, the increase in islet volume and consequent $\beta$-cell hyperplasia appears to be an effective means of maintaining blood sugar concentrations at near normal levels. In contrast, neither the diabetic sand rat [5] nor the diabetia mouse has hypertrophied islets and neither effectively controls blood sugar levels.

Although the early onset of diabetes in $d b$ mice coincides with that in juvenile diabetes in man, the symptoms of obesity and elevated serum insulin are more suggestive of the pattern of development observed in the maturity-onset type of diabetes. As yet, none of the lesions associated with advanced diabetes in humans such as retinopathies, cardiovascular and kidney lesions have been observed, possibly because of the early onset of the diabetes and the relatively rapid deterioration and death of these mice. If by nutritional means, drug therapy, or genetic manipulation, the diabetic condition can be made chronic rather than acute, lesions may become grossly visible. The use of more sophisticated methods of examination of organs and tissue will, undoubtedly, yield more information with regard to subtle changes.

Several advantages presented by this mutant diabetic mouse in the study of diabetes mellitus are readily apparent. The mutation arose and is being maintained in an inbred strain, facilitating studies involving tissue and organ transplantations and obviating the necessity of using litter-mate controls. The proportion of diabeties that will result from mating between genetic types can be predicted with certainty, since the inheritance is known to be under the control of a recessive gene with complete penetrance. Offspring that will exhibit the diabetic syndrome can be distinguished from those that will not, as early as 3 weeks after birth.

Some disadvantages are equally apparent. Diabetic homozygotes do not breed, and heterozygotes cannot be distinguished from normals except by progeny testing. The onset of obesity and diabetes at the weaning age, means that studies of preclinical stages of the disease can be undertaken for a very short period if at all. It is possible that genetic manipulation, such as outcrossing to another inbred strain, will result in the introduction of genetic modifiers that will change the course and severity of the disease. Ovary transplantation has been successfully used in producing diabetic offspring, and if this technique can be coupled with artificial insemination, litters composed entirely of diabetics will result, greatly facilitating detailed studies of preclinical stages.

Acknowtedgment. The technical assistance of Mr. R.H. Copp, Mrs. Eleanor McFarland, and Mrs. Dorotmy ChAPMAN is gratefully acknowledged.

\section{References}

[1] Fenton, P.F., and C.J. CARR: The nutrition of the mouse. $X$. Studies on the utilization of high and moderately low protein diets for growth in four strains of mice. J. Nutr. 43, 441-450 (1951).

[2] Folch, J., I. Ascoli, M. Lefis, J.A. Mrath and F. N. LeBaron: Preparation of lipid extracts from brain tissue. J. biol. Chem. 191, 833 - 841 (1951). 
[3] Folin, O., and H. Marinros: Improved form of Folin's micromethod for blood sugar determinations. J. biol. Chem. 83, 115-120 (1929).

[4] Gonet, A.E., W. Stauffacher, R. Pictet and A.E. RENOLD : Obesity and diabetes mellitus with striking congenital hyperplasia of the islets of Langerhans in spiny mice (Acomys Cahirinus). T. Histological findings and preliminary metabolic observations. Diabetologia 1, $162-171(1965)$.

[5] Hackel, D.B., L. Frohman, E. Minat, H. E. LebovITZ, K. SCHMIDT-NIELSEN and T.D. KINNEY : Effect of diet on the glucose tolerance and plasma insulin levels of the sand rat (Psammomys obesus). Diabetes 15, 105- 114 (1966).

[6] HALES, C.N., and P.J. RANDLE: Immunoassy of insulin with insulin-antibody precipitate. Biochem. J. 88, 137-146 (1963).

[7] HaLmi, N.S.: Differentiation of two types of basophils in the adenohypophysis of the rat and the mouse. Stain Technol. 27, 61-64 (1952).

[8] Hassid, W.Z., and S. ABraHaM: Methods of Enzymology. Vol. 1, p. 35. New York: Academic Press 1955.

[9] Hausberger, F.X., and A.J. Ramsay : Islet hypertrophy in obesity of mice bearing ACTH tumors. Endocrinology 65, 165-171 (1959).

[10] Hhitmerström, C., and B. Heulman: The islets of Langerhans in yellow obese mice. Metabolism 12, $527-536(1963)$.

[11] Hummer, K.P., M.M. Didkie and D.L. Colmman: Diabetes, a new mutation in the mouse. Science 153, $1127-1128(1966)$.

[12] Kornacker, M.S., and J.M. Löwenstein: Citrate cleavage and acetate activation in livers of normal and diabetic rats. Biochim. biophys. Acta 84, $490-492$ (1964)

[13] KorNBERG, A., and B.L. HoreckFr: Mothods of Enzymology, Vol. 1. p. 323. New York: Academic Press 1955.

[14] LruIE, R.D.: Histopathologic Technic and Practical Histochemistry. 3rd ed. p. 39. New York: McGraw Hill 1965.
[15] MAYER, J.: The obese-hyperglycemic syndrome of mice as an example of metabolic obesity. Amer. J. clin. Nutr. 8, 712-718 (1960).

[16] MoGtuvery, R.W.: Methods of Enzymology, Vol. II. p. 543. New York: Academic Press 1955.

[17] Nakamura, M.: Cytological and histological studies on the pancreatic islets of a diabetic strain of the mouse. Z. Zellforsch. 65, 340-349 (1965).

[18] Sharma, C., R. Manheshwar and S. WEInHouse: Effects of diet and insulin on glucose-adenosine triphosphate phosphotransferases of rat liver. J. biol. Chem. 238, 3840-3845 (1963).

[19] SNEyd, J.G.T.: Pancreatic and serum insulin in the New Zealand strain of obese mice. J. Endocr. 28, $163-172$ (1964).

[20] Swanson, M.J.: Methods of Enzymology Vol. II. p. 541. New York: Academic Press 1955.

[21] UTter, M.F., and D.B. KeECH: Pyruvate carboxylase. I. Nature of the Reaction. J. biol. Chem. 238, 2603-2608 (1963).

[22] - , and K. KURAKashi: Methods of Enzymology, Vol. 1, p. 758. New York: Academic Press 1955.

[23] VALLANCE-Owen, J.: Synalbumin antagonism in obesity and maturity onset diabetes mellitus. Ann. N. Y. Acad. Sci. 131, 315-323 (1965).

[24] WarburG, O., and W. Christiax: Isolation and crystallization of enolase. Biochem. Z. 310, 385-421 1942.

[25] Weber, G., and H.J.H. Convery: Insulin: Tnducer of glucose-6-phospate dehydrogenase. Life Sciences 5, 1139-1144 (1966).

[26] - R.L. Singhat, M.B. Stamin, E.A. Fisher and M. A. Metendiak: Advances in Enzyme Regulation. New York, Macmillan Company,Vol.2, p.1-38, 1964.

[27] Young, F.G.: Insulin and insulin antagonism. Endocrinology 73, 654-664 (1963).

Douglas L. Coleman, Ph.D.

The Jackson Laboratory

Bar Harbor, Maine, U.S.A. 